\title{
Appraisal of Heavy Metals Uptake Capacities of 2 Edible Vegetables (Amaranthus caudatus and Amaranthus hybridus) from Natural, Heavy Metals and Urea Fertilizer-Enriched Soils: Towards Family Health Security
}

\author{
Anthony A. Izuagie ${ }^{1 *}$, Uzezi E. Amuho ${ }^{1}$ and Folasade O. Izuagie ${ }^{2}$ \\ ${ }^{1}$ Department of Chemistry, Adeyemi Federal University of Education, Ondo, Nigeria. \\ ${ }^{2}$ Department of Home Economics, Adeyemi Federal University of Education, Ondo, Nigeria. \\ ${ }^{*}$ Corresponding Author E-mail: aaizuagie@gmail.com +2348037621226
}

Received 13 January 2022; Accepted 18 February 2022; Published 24 February 2022

\begin{abstract}
Heavy metals uptake capacities of 2 edible vegetables (Amaranthus caudatus (soko) and Amaranthus hybridus (tete)) from natural, metals and fertilizer enriched soils were evaluated to establish their safety for family consumption. Oxides of $\mathrm{Fe}, \mathrm{Cu}$, $\mathrm{Pb}$ and $\mathrm{Zn}$ giving equivalents of $800 \mathrm{mg} \mathrm{Fe} \mathrm{kg}^{-1}, 500 \mathrm{mg} \mathrm{Cu} \mathrm{kg}{ }^{-1}, 1500 \mathrm{mg} \mathrm{Pb} \mathrm{kg}^{-1}$ and $700 \mathrm{mg} \mathrm{Zn} \mathrm{kg}{ }^{-1}$ respectively were measured into each of the 4 pots containing $2.5 \mathrm{~kg}$ of soil. Two grams of urea fertilizer were weighed into 2 of the pots with added metals and mixed. Seeds of the 2 vegetables were planted inside the pots and labelled. Two pots served as controls. The pots were watered and germination occurred within $5 \mathrm{~d}$. Seedlings were thinned to one stand per plant. Vegetables were harvested after 34 $\mathrm{d}$ and each separated into shoot and root, dried in the oven at $60^{\circ} \mathrm{C}$ for $1 \mathrm{~h}$ and then at $110^{\circ} \mathrm{C}$ for $5 \mathrm{~h}$. Dry samples were crushed, weighed and ashed in the furnace at $600{ }^{\circ} \mathrm{C} . \mathrm{HNO}_{3}$ solutions of the ashes were analyzed using Buck Scientific 210 Atomic Absorption Spectrophotometer. Results showed that the shoots of the vegetables contained less metal concentration the roots with Amaranthus hybridus having higher values. Fertilizer application increased the metal concentrations in the shoot of Amaranthus hybridus with the levels of $\mathrm{Pb}(6.65 \mathrm{mg} / \mathrm{kg})$ and $\mathrm{Fe}(10.54 \mathrm{mg} / \mathrm{kg})$ being higher than the FAO/WHO maximum limits of 0.3 and $2.5 \mathrm{mg} / \mathrm{kg}$ respectively for leafy vegetables. Amaranthus hybridus without applied fertilizer is safer for consumption.
\end{abstract}

Keywords: Heavy metal, uptake capacities, vegetables, soil, fertilizer

\section{INTRODUCTION}

Heavy metals are significant environmental pollutants and their toxic effects are of increasing significance for ecological, evolutionary, nutritional and environmental reasons (Nagajyoti et al., 2021; Jaishankar et al., 2014). Heavy metals like $\mathrm{Zn}, \mathrm{Cu}, \mathrm{Fe}, \mathrm{Mn}$ and $\mathrm{Co}$ are essential metals needed by plants in trace amounts for growth and various metabolic activities. However, these elements can have adverse effect on plant growth if their concentrations are greater than the permissible levels in their substrates (Garrido et al., 2002; Rascio and Izzo, 2011).
Some heavy metals like $\mathrm{As}, \mathrm{Cd}, \mathrm{Pb}$ and methylated forms of $\mathrm{Hg}$ do not play any biological functions. Their intake at even very low concentrations can be toxic to biological systems (Duruibe et al., 2007; Kazemipour et al., 2008).

Human exposure to heavy metal toxicity may occur if the food chain consists of heavy metals which have been accumulated through uptake by plants cultivated on soils contaminated with heavy metals (Sprynskyy et al., 2007). The cultivation of such plants on contaminated soils portends a potential health risk since the plant tissue 
accumulate heavy metals (Jordao et al., 2006). Toxicity of heavy metals occurs when they are not metabolized in the body and accumulate in the soft issues (Sobha et al., 2007). $\mathrm{Pb}$ distribution in human body initially depends on the blood flow into various tissues with about $95 \%$ of the metal deposited in the form of insoluble phosphate in skeletal bones (Papanikolaou et al., 2005). Pb toxicity can be either acute or chronic. Acute toxicity may cause loss of appetite, headache, hypertension, fatigue, sleeplessness, arthritis, dysfunction in the kidney, reproduction system, liver and brain resulting in sickness and death (Odum, 2000; Martin and Griswold, 2009).

Fe is the most abundant trace metal in the body and is an essential element in most biological systems (Greentree and Hall, 1995; Goyer, 1996). However, excess $\mathrm{Fe}$ in the body should be avoided because $\mathrm{Fe}$ is toxic to cells in excess. The toxicity of $\mathrm{Fe}$ has always been a topic of concern to pediatricians. $\mathrm{Fe}$ is responsible for unintentional poisoning in children through exposure to high Fe content products (Albretsen, 2006). Absorption of Fe occurs in two steps. First, Fe ions are absorbed from intestine into the mucosal cells.

Although $\mathrm{Fe}$ II is better absorbed than Fe III (Fe III precipitates out of solution around $\mathrm{pH} 7$ ), both ions can be absorbed if they are iodized (Greentree and Hall, 1995; Goyer, 1996; Hillman, 1995). It is rather unfortunate that very little $\mathrm{Fe}$ is lost from the body through urine or faeces. Fe loss is notably not increased even after Fe overdoses (Greentree and Hall, 1995; Osweiler et al., 1985). Where around $2 \%$ to $15 \%$ of the $\mathrm{Fe}$ ingested is absorbed, only about $0.01 \%$ of the $\mathrm{Fe}$ body burden is removed daily (Goyer, 1996; Hillman, 1995). Cu is an essential element as a component of metalloenzymes where it acts as an electron donor or acceptor (Stern et al., 2007). Cu is not considered to be mutagenic, carcinogenic or affect reproduction (Joint FAO/WHO, 2011).

$\mathrm{Zn}$ is not considered to be a toxic metal. No adverse effect was recorded for the metal consumption even at an intake of $600 \mathrm{mg}$ of $\mathrm{ZnSO}_{4}$, equivalent to $200 \mathrm{mg}$ of elemental (Joint FAO/WHO, 2011).

The effect of plant uptake of heavy metals from soil in which fertilizer is applied depends on whether the soil is polluted by heavy metals or not. It was reported that $\mathrm{Zn}$ and $\mathrm{Cd}$ concentrations in the wheat Triticum vulgare from uncontaminated soil fertilized with urea were higher than those of the control (without fertilizer) while the concentrations of the same metals were less in the wheat from the fertilized metal-contaminated soil than those of the control (Shtangeeva et al., 2004). The concentrations of $\mathrm{Cu}$ and $\mathrm{Pb}$ in the wheat from the fertilized metalcontaminated and uncontaminated soils were higher than the values obtained from their respective controls. However, $\mathrm{Cu}$ concentration in the wheat from the fertilized contaminated soil was not significantly higher that the concentration observed for the wheat in the control.

This study was carried out to determine the extent to which $A$. caudatus and $A$. hybridus, 2 edible vegetables, would uptake heavy metals from metal contaminated soils and contaminated soils containing urea fertilizer.

\section{MATERIALS AND METHODS}

\section{Sample collection}

Top soil was obtained from an uncontaminated and uncultivated land. Stones and debris were hand-picked from the soil before sun drying for $14 \mathrm{~d}$. The dry soil was filtered using a $2 \mathrm{~mm}$ mesh sieve. Even particle distribution was ensured by a thorough mixing of the soil. The soil was then stored in a clean polythene until use. Dry seeds of $A$. caudatus and $A$. hybridus were purchased from a vegetable market in Ondo town, Ondo State, Nigeria. The seeds were further air-dried in small trays in the laboratory for $3 \mathrm{~d}$ after which they were stored in a laboratory cupboard in 2, small sealed paper bags with labels for identification.

\section{Vegetable pots preparation}

There were 6 perforated black plastic pots for the experiment. Three pots were for each of the 2 species of vegetable. One out of the 3 pots was for the control, which had the vegetable and soil only. The second pot contained the vegetable and soil impregnated only with the oxides of the heavy metals under study, while the third pot contained the vegetable and soil impregnated with the oxides of heavy metals and urea fertilizer.

A mass of $2.5 \mathrm{~kg}$ of soil was weighed into each of the control pots without adding metal oxides or fertilizer. Four separate sets of masses of $\mathrm{Fe}_{2} \mathrm{O}_{3}, \mathrm{CuO}, \mathrm{PbO}$ and $\mathrm{ZnO}$ corresponding to $800 \mathrm{mg} \mathrm{Fe} \mathrm{kg}^{-1}, 500 \mathrm{mg} \mathrm{Cu} \mathrm{kg}^{-1}, 1500$ $\mathrm{Pb} \mathrm{kg}-1$ and $700 \mathrm{mg} \mathrm{Zn} \mathrm{kg}^{-1}$ were weighed, pooled and mixed thoroughly together to ensure homogeneity. Each complete set of mixed oxides was added to $2.5 \mathrm{~kg}$ of soil with a thorough mixing before transferring into each of the remaining 4 pots. A mass of $2 \mathrm{~g}$ of urea fertilizer was weighed into 2 of the 4 pots impregnated with metal oxides. All the pots were seated inside equal-sized black plastic bowls serving as supports for the pots. Each of the plastic support made a close fit with the pot at a level close to the base of pot and served as leachate retainers. The pots containing $A$. caudatus were labelled $A 1, A 2$ and $A 3$, where $A 1$ was the control pot while $A 2$ contained the vegetable in soil impregnated with metal oxides and A3 contained vegetable in soil impregnated with both metal oxides and fertilizer. 
The pots containing $A$. hybridus were labelled $B 1, B 2$ and $B 3$ with $B 1$ as the control pot while the contents of $B 2$ and $B 3$ were as described for $A 2$ and $A 3$ respectively, but containing $A$. hybridus. The 6 pots were placed in an open wooden box that served as a greenhouse. All the sides and the top of box were covered with a white net. The box was placed where it could assess optimum daylight but protected from strong wind and rain.

\section{Seed planting, germination and harvest}

The seeds of the vegetables were planted in all the 6 pots on the same day. Same volume of deionized water was sprinkled carefully on the soil after seed planting. Germination occurred within $5 \mathrm{~d}$ of planting. Watering was done when necessary while ensuring same treatment for all the pots. The seedlings were thinned to one seedling per pot after 1 week of germination. The seedlings removed were placed inside the respective pots to avoid loss of material. The plants grew to maturity except the $A$. caudatus plant in the pot labelled $A 2$, containing soil enriched with metals only. The plant died a few days after germination. The experience occurred even with repeated planting of the seeds. The plants in the other 5 pots were harvested after 34 days of planting.

\section{Sample preparation for analysis}

The harvested plants were washed and rinsed with deionized water. After air drying, each plant was separated into shoot and root. The shoots and the roots were dried in an oven, first at $60^{\circ} \mathrm{C}$ for $1 \mathrm{~h}$ and then at $110{ }^{\circ} \mathrm{C}$ for $5 \mathrm{~h}$ after which they were cooled in a desiccator. The dry shoots and roots were crushed separately into powder, weighed and transferred into porcelain crucibles for ashing in the furnace at a temperature of $600^{\circ} \mathrm{C}$. The dry weights of the respective shoots and roots are reported in (Table 1). The subscript "S" was added to the labels of vegetable samples to indicate the respective shoot samples while the subscript "R" was added to the labels to indicate root samples. All the samples were brought out of the furnace when there were no longer traces of dark portions in the ashes. The samples were cooled in air on a steel tray. The ash of each sample was transferred into a $100 \mathrm{~mL}$ Pyrex beakers while dissolution was achieved by adding $40 \mathrm{~mL}$ of $1 \mathrm{M} \mathrm{HNO}_{3}$.

The metal solutions in the beakers were poured into graduated measuring cylinders while the beakers were rinsed into the cylinders with distilled water. The final volume of each sample solution was made up to $60 \mathrm{~mL}$ and stored in metal-free, colorless polythene bottles with cover.

\section{Metal analysis by AAS}

Heavy metals in the sample solutions were analyzed using Buck Scientific 210 Atomic Absorption Spectrophotometer at the Federal University of Technology, Akure, Ondo State, Nigeria. The concentrations of evaluated heavy metals in the solutions of samples are reported in (Tables 2 and 3). The concentrations were converted to $\mathrm{mg}$ of metal per kg dry weight of the respective shoots and roots of the vegetables.

\section{RESULTS AND DISCUSSION}

\section{The dry weights of the shoots of the 2 species of $A$. vegetables}

The masses of the dried shoots and roots of the experimental vegetable plants are presented in (Table 1). No value is recorded for the shoot and root of $A 2$ because the plant did not survive in the pot.

\section{Analysis of samples by AAS}

The results of the concentrations of the evaluated heavy metals in solutions of plants' shoot and root samples are reported in (Tables 2 and 3 ) respectively. The corresponding values of the metal concentrations expressed in $\mathrm{mg}$ of metal per $\mathrm{kg}(\mathrm{mg} / \mathrm{kg})$ of dry shoot or root of vegetables are given in (Tables 4 and 5). Subscripts $S$ and $R$ in the samples denote shoot and root respectively.

The results in (Table 4) show that the $\mathrm{Pb}$ concentrations of most of the vegetable samples were below the maximum limit defined by FAO/WHO (2011) for lead in vegetable. The control of $A$. caudatus presented a $\mathrm{Pb}$ concentration of shoot around the set limit. While the use of fertilizer might not pose any danger in terms of bioavailability of $\mathrm{Pb}$ in the shoot of $A$. caudatus, the same might not be said of $A$. hybridus as there was a significant increase in $\mathrm{Pb}$ concentration to $6.65 \mathrm{mg} / \mathrm{kg}$ with the use of fertilizer in the soil enriched with heavy metals (B3s). Fertilizer should therefore not be applied to a lead-rich soil in which this vegetable ( $A$. hybridus) is cultivated to avoid lead poisoning.

Comparatively, the shoots of $A$. hybridus appeared to accumulate more metals than the shoots of $A$. caudatus for soils containing high levels of heavy metals and the soils in which fertilizer was applied. Lack of shoot samples of $A$. caudatus from the soil enriched with metals only $\left(A 2_{S}\right)$ shows that $A$. caudatus has a low tolerance for heavy metal-polluted soils. While the application of fertilizer to the soil enriched with metals increased the 
Table 1: Dry weights of shoots and roots of harvested vegetable samples.

\begin{tabular}{lcc}
\hline Vegetable sample & Dry weight of shoot $(\mathbf{g})$ & Dry weight of root $\mathbf{( g )}$ \\
\hline$A 1$ & 3.8 & 0.5 \\
$A 2$ & - & - \\
$A 3$ & 4.2 & 0.7 \\
$B 1$ & 5.4 & 1.5 \\
$B 2$ & 2.6 & 0.4 \\
$B 3$ & 1.5 & 0.3 \\
\hline
\end{tabular}

Table 2: Concentrations of heavy metals in the solutions of shoot ashes of vegetables in $\mathrm{mg} / \mathrm{L}$.

\begin{tabular}{lcccccc}
\hline \multicolumn{3}{c}{ Amaranthus caudatus } & \multicolumn{3}{c}{ Amaranthus hybridus } \\
\hline Metals & $\boldsymbol{A 1 s}$ & $\boldsymbol{A 2 s}$ & $\boldsymbol{A 3 s}$ & $\boldsymbol{B 1 s}$ & $\boldsymbol{B 2 s}$ & $\boldsymbol{B 3 s}$ \\
\hline $\mathrm{Pb}$ & 0.0196 & - & $\mathrm{ND}$ & $\mathrm{ND}$ & $\mathrm{ND}$ & 0.1663 \\
$\mathrm{Zn}$ & 0.7011 & - & 0.1512 & 0.5346 & 0.0585 & 0.1440 \\
$\mathrm{Fe}$ & 0.1906 & - & 0.1120 & 0.0981 & 0.0589 & 0.2635 \\
$\mathrm{Cu}$ & 0.0323 & - & 0.0182 & $\mathrm{ND}$ & $\mathrm{ND}$ & 0.0085 \\
\hline
\end{tabular}

ND $=$ Not detected.

Table 3: Concentrations of heavy metals in the solutions of root ashes of vegetables in $\mathrm{mg} / \mathrm{L}$

\begin{tabular}{lcccccc}
\hline & \multicolumn{3}{c}{ Amaranthus caudatus } & \multicolumn{3}{c}{ Amaranthus hybridus } \\
\hline Metals & $\boldsymbol{A 1}_{\boldsymbol{R}}$ & $\boldsymbol{A 2}_{\boldsymbol{R}}$ & $\boldsymbol{A 3}_{\boldsymbol{R}}$ & $\boldsymbol{B 1}_{\boldsymbol{R}}$ & $\boldsymbol{B 2}_{\boldsymbol{R}}$ & $\boldsymbol{B 3}_{\boldsymbol{R}}$ \\
\hline $\mathrm{Pb}$ & $\mathrm{ND}$ & - & $\mathrm{ND}$ & $\mathrm{ND}$ & 0.0208 & $\mathrm{ND}$ \\
$\mathrm{Zn}$ & 0.1710 & - & 0.8820 & 0.2790 & 0.4591 & 0.2700 \\
$\mathrm{Fe}$ & 0.0273 & - & 0.0254 & 0.1725 & 1.0807 & 0.0818 \\
$\mathrm{Cu}$ & $\mathrm{ND}$ & - & $\mathrm{ND}$ & 0.0085 & 0.6069 & 0.0128 \\
\hline
\end{tabular}

$\mathrm{ND}=$ Not detected.

Table 4: Concentrations of heavy metals in the shoot ashes of vegetables in $\mathrm{mg} / \mathrm{kg}$.

\begin{tabular}{lccccccc}
\hline Metals & \multicolumn{8}{c}{ Amaranthus caudatus } & \multicolumn{6}{c}{ Amaranthus hybridus } & Maximum limit \\
\hline & $\boldsymbol{A 1} \boldsymbol{s}$ & $\boldsymbol{A 2 s}$ & $\boldsymbol{A 3 s}$ & $\boldsymbol{B 1} \boldsymbol{s}$ & $\boldsymbol{B 2 s}$ & $\boldsymbol{B 3 s}$ & \\
\hline $\mathrm{Pb}$ & 0.31 & - & $\mathrm{ND}$ & $\mathrm{ND}$ & $\mathrm{ND}$ & 6.65 & 0.3 \\
$\mathrm{Zn}$ & 11.07 & - & 2.16 & 5.94 & 1.35 & 5.76 & - \\
$\mathrm{Fe}$ & 3.01 & - & 1.36 & 1.09 & 1.36 & 10.54 & 2.5 \\
$\mathrm{Cu}$ & 0.51 & - & 0.26 & $\mathrm{ND}$ & $\mathrm{ND}$ & 0.34 & - \\
\hline
\end{tabular}

${ }^{*}$ Maximum limits of metals in vegetables (FAO/WHO, 2011).

levels of metals in the shoots of $A$. hybridus, its application reduced the bioavailability of heavy metals in the shoot of $A$. caudatus, even below the levels obtained for its control. Fertilizer application may therefore be necessary to ensure low heavy metal uptake by cultivated $A$. caudatus.

The calculated $t$ for the individual differences between the metals from the two controls, $A 1_{s}$ and $B 1_{s}$ for $A$. caudatus and $A$. hybridus respectively was 1.77 where the tabulated $t$ at $80 \%$ confidence level and 3 degrees of freedom is 1.64. It therefore follows that the respective metal concentrations were significantly different from each other for the two vegetables with $A$. caudatus having higher metal concentrations. The shoot of $A$. caudatus cultivated on soil free of heavy metal pollution was richer in $\mathrm{Zn}$ and $\mathrm{Cu}$ than the other vegetable cultivated on a similar soil.

Table 5 shows much higher concentrations of metals in the roots of the vegetables than the corresponding values in shoots as shown in (Table 4). The trend in the bioavailability of metals in the roots of the plant is different from that of the shoots considering samples $B 2_{R}$ and $B 3_{R}$. For $A$. hybridus, the control sample contained the least metal concentrations in the root while the sample from soil enriched only with metals contained the highest concentrations of metals with concentrations far exceeding the FAO/WHO (2011) maximum limits for the metals in vegetables. Application of fertilizer to the metalenriched soil $\left(B 3_{R}\right)$ reduced the bioavailability of the heavy metals in the root of the plant significantly. 
Table 5: Concentrations of heavy metals in the root ashes of vegetables in $\mathrm{mg} / \mathrm{kg}$.

\begin{tabular}{lccccccc}
\hline \multicolumn{7}{c}{ Amaranthus caudatus } & \multicolumn{6}{c}{ Amaranthus hybridus } \\
\hline Metals & $\boldsymbol{A 1}_{\boldsymbol{R}}$ & $\boldsymbol{A 2}_{\boldsymbol{R}}$ & $\boldsymbol{A 3} \boldsymbol{B}$ & $\boldsymbol{B 1}_{\boldsymbol{R}}$ & $\boldsymbol{B 2}_{\boldsymbol{R}}$ & $\boldsymbol{B 3}_{\boldsymbol{R}}$ & ${\text { Maximum } \text { limit }^{\boldsymbol{*}}}^{\mathrm{Pb}}$ \\
$\mathrm{ND}$ & - & $\mathrm{ND}$ & $\mathrm{ND}$ & 3.12 & $\mathrm{ND}$ & 0.3 \\
$\mathrm{Zn}$ & 20.52 & - & 75.60 & 11.16 & 68.86 & 54.00 & - \\
$\mathrm{Fe}$ & 3.27 & - & 2.18 & 6.90 & 162.10 & 16.35 & 2.5 \\
$\mathrm{Cu}$ & $\mathrm{ND}$ & - & $\mathrm{ND}$ & 0.34 & 91.03 & 2.56 & - \\
\hline
\end{tabular}

*Maximum limits of metals in vegetables (FAO/WHO, 2011).

In $A$. caudatus, fertilizer application to soil increased the bioavailability of $\mathrm{Zn}$ from $20.52 \mathrm{mg} / \mathrm{kg}$ to $75.60 \mathrm{mg} / \mathrm{kg}$ but decreased the bioavailability of Fe slightly (from 3.27 $\mathrm{mg} / \mathrm{kg}$ to $2.18 \mathrm{mg} / \mathrm{kg}$ ) in the root. There are no defined maximum limits for $\mathrm{Zn}$ and $\mathrm{Cu}$ by FAO/WHO (2011).

\section{Conclusion}

The following are the highlights of the outcome of the study:

- There is a significant difference between the metal uptake capacity of the shoot of $A$. caudatus and that of the $A$. hybridus cultivated on the metal contamination-free soils (controls) as established with Paired $t$ - test, with the former having higher metal concentrations. Therefore, consumption of $A$. hybridus cultivated on metal contamination-free soil is safer for less of heavy metal uptake into shoots.

- $\quad$ Application of urea fertilizer to soil decreased the bioavailability of $\mathrm{Pb}, \mathrm{Zn}, \mathrm{Fe}$ and $\mathrm{Cu}$ in the shoot of $A$. caudatus but caused a significant increase in the concentrations of the metals in the shoot of $A$. hybridus.

- $\quad$ Bioavailability of the metals in the roots of the 2 plants decreased with application of urea fertilizer.

\section{Acknowledgements}

This study was possible because of the support given by the Department of Chemistry, Adeyemi Federal University of Education, Ondo, through the provision of the requisite chemicals and greenhouse for the plants.

\section{REFERENCES}

Albretsen, J. (2006). The toxicity of iron, an essential element. Veterinary Medicine. 82-90.

Duruibe, J. O., Ogwuegbu, M. O. C. and Egwurugwu, J. N. (2007). Heavy metal pollution and human biotoxic effects. International Journal of Physical Sciences. Vol. 2(5), 112-118.

Garrido, S., Campo, G. M. D., Esteller, M. V., Vaca, R. and Lugo, J. (2002). Heavy metals in soil treated with sewage sludge composting, their effect on yield and uptake of broad been seeds (Vicia faba L.). Water, Air and Soil Pollution. Vol. 166, 303-319.
Goyer, R. A. (1996). Toxic effects of metals. In: Klaassen CD, ed. Casarett and Doull's Toxicology: The Basic Science of Poisons. 5th Ed. New York City, NY: McGraw-Hill. Pp. 715-716.

Greentree, W. F. and Hall, J. O. (1995). Iron toxicosis. In: Bonagura JD, ed. Kirk's Current Therapy XII Small Animal Practice. Philadelphia, Pa: WB Saunders Co. 240-242.

Hillman, R. S. (1995). Hematopoietic agents: growth factors, minerals, and vitamins. In: J. G. Hardman, L. E. Limbird, P. B. Molinoff et al., eds. Goodman and Gilman's The Pharmacological Basis of Therapeutics. 9th Ed. New York City, NY: McGraw-Hill. Pp. 13111340.

Jaishankar, M., Mathew, B. B. Shah, M. S. and Gowda, K. R. S. (2014). Biosorption of few heavy metal ions using agricultural wastes. Journal of Environment Pollution and Human Health. Vol. 2(1), 1-6.

Joint FAO/WHO Food Standards Programme CODEX Committee on Contaminants in Foods (2011). Working document for information and use in discussions related to contaminants and toxins in the GSCTFF The Hague, The Netherlands, 21-25 March 2011.

Jordao, C. P., Nascentes, C. C., Cecon, P. R., Fontes, R. L. F., and Pereira, J. L. (2006). Heavy metal availability in soil amended with composted urban solid wastes. Environmental Monitoring and Assessment. Vol. 112, 309-326.

Kazemipour, M., Ansari, M., Tajrobehkar, S., Majdzadeh, M. and Kermani, H. R. (2008). Removal of lead, cadmium, zinc and copper from industrial wastewater by carbon developed from walnut, hazelnut, almond, pistachio shell and apricot stone. Journal of Hazardous Materials. Vol. 150, 322-327.

Martin, S. and Griswold, W. (2009). Human health effects of heavy metals. Environmental Science and Technology Briefs for Citizens. Vol. 15, 1-6.

Nagajyoti, P. C., Lee, K. D. and Sreekanth, T. V. M. (2010). Heavy metals, occurrence and toxicity for plants: a review. Environmental Chemistry Letters. Vol. 8(3), 199-216.

Odum, H. T. (2000). Background of published studies on lead and wetlands. In: Howard T. Odum (Ed), Heavy metals in the Environment Using Wetlands for Their Removal. New York, USA: Lewis Publishers.

Osweiler, G. D., Carson, T. L., and Buck, W. B., et al. (1985). Iron. In: Clinical and Diagnostic Veterinary Toxicology. 3rd Ed. Dubuque, lowa: Kendall/Hunt Publishing Co. Pp. 104-106.

Papanikolaou, N. C., Hatzidaki, E. G., Belivanis, S., Tzanakakis, G. N. and Tsatsakis, A. M. (2005). Lead toxicity update. A brief review. Medical Science Monitor. Vol. 11(10), RA329-36.

Rascio, N. and Izzo, F. N. (2011). Heavy metal hyperaccumulating plants: how and why do they do it? And what makes them so interesting? Plant Science. Vol. 180, 169-181.

Shtangeeva, I., Luiho, J. V-P, Kahelin, H. and Gobran, G. R. (2004). Improvement of phytoremediation effects with help of different fertilizers, Soil Science and Plant Nutrition, Vol. 50(6), 885-889.

Sobha, K., Poornima, A., Harini, P. and Veeraiah, K. (2007). A study on biochemical changes in the freshwater fish, catla catla (Hamilton) exposed to the heavy metal toxicant cadmium chloride. Kathmandu University Journal of Science, Engineering and Technology. Vol. 19(4), 1-11.

Sprynskyy, M., Kosobucki, P., Kowalkowski, T. and Buszewsk, B. 
(2007). Influence of clinoptilolite rock on chemical speciation of selected heavy metals in sewage sludge. Journal of hazardous Materials. Vol. 149, 310-316.

Stern, B. R., Solioz, M., Krewski, D., Aggett, P., Aw, T. C., Baker, S., Crump, K., Dourson, M., Haber, L., Hertzberg, R., Keen, C., Meek, B., Rudenko, L., Schoeny, R., Slob, W. and Starr T. (2007). Copper and human health: biochemistry, genetics, and strategies for modeling doseresponse relationships. Journal of Toxicology and Environmental Health, Part B, Vol. 10, 157-222. 